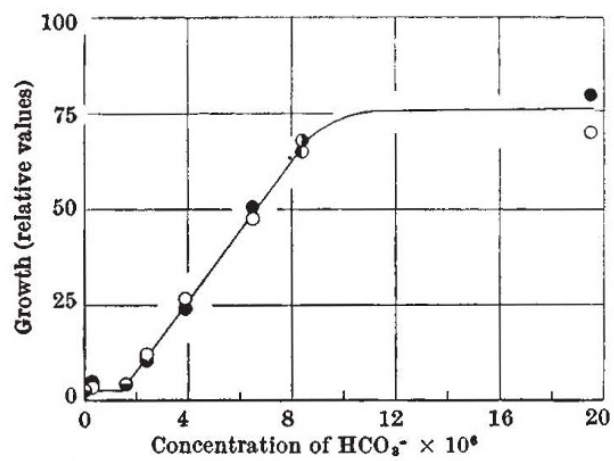

Fig. 2. GROWTH OF Scenedesmus quadricauda AT VARIOUS CONCENTRATIONS OF BICARBONATE IONS

The slight growth below $1.5 \mu \mathrm{mol}$./1. must be ascribed to the free carbon dioxide or carbonic acid, the concentration of which is $10 \mu \mathrm{mol} . / 1$. at all $p \mathrm{H}$ values. A strange fact is that bicarbonate in concentrations below $1.5 \mu \mathrm{mol}$./ 1 . was not assimilated. At bicarbonate concentrations greater than $9 \mu \mathrm{mol} . / 1$, growth is no longer limited by this substance but by other factors.

Steemann Nielsen (loc. cit.) has found that Myriophyllum and Fontinalis use carbon dioxide more rapidly than bicarbonate ions. In the case of Scenedesmus, we see that in a carbon dioxide concentration of $10 \mu \mathrm{mol} . / \mathrm{l}$., growth is very small; but in the same concentration of bicarbonate ion the growth amounts to 75 per cent of the optimal growth. Thus we see that various plants behave very differently with regard to the carbon source: Fontinalis assimilates about ten times better in carbon dioxide than in bicarbonate, and Myriophyllum two to five times better; but Scenedesmus grows twenty-five times better in bicarbonate than in carbon dioxide.

From Steemann Nielsen's curves one can see that the ability to use carbon dioxide is about the same for Myriophyllum and Fontinalis. The assimilation at $10 \mu \mathrm{mol}$. $/ \mathrm{l}$. of carbon dioxide is very slow ; and this is also the case with Scenedesmus. The differences are to be found instead in the ability to use bicarbonate. Fontinalis has a very slow assimilation in $10 \mathrm{mmol}$. of bicarbonate per litre, the assimilation of Myriophyllum amounts to 50 per cent of the optimal at $1 \mathrm{mmol} . / \mathrm{l}$, and Scenedesmus has 75 per cent of its optimal growth at $0.01 \mathrm{mmol}$./1.

It is very probable that these facts aficet the distribution of the plants in lakes.

SVEN ÖSTERLIND

Institute of Physiological Botany,

University of Uppsala. Nov. 12.

2 Steemann Nielsen, E., Nature, 158, 594 (1946).

- Osterlind, S., Nature, 159, 199 (1947).

\section{A Chætomium-like Thermophile Fungus}

Among the various organisms which have been isolated at this Station from fermenting straw composts, one, M.R.A. No. 112, is of special interest. It is a thermophile Ascomycete producing perithecia which in many respects resemble those of the genus Choetomium.

Between the temperatures $40^{\circ} \mathrm{C}$. and $50^{\circ} \mathrm{C}$., on slopes of 3 per cent malt extract agar, $p \mathrm{H} 5 \cdot 5$, in a saturated atmosphere, vegetative growth is most luxuriant and perithecia are most abundant and most fertile. At $45^{\circ} \mathrm{C}$. a small amount of mycelium deposited about the centre of a slope $7 \mathrm{~cm} . \times 1.5 \mathrm{~cm}$.

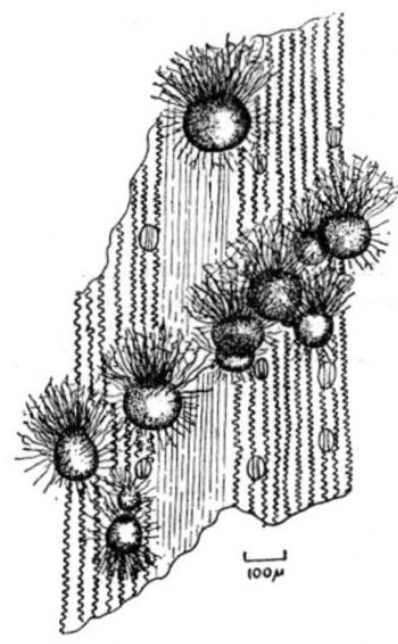

PERITHECIA OF THERMOPHILE FUNGUS, M.R.A. No, 112 , ON PIECE OF STRAW, APPROX. $\times 40$ (SEMI-DLAGRAMMATIC)

spreads over the whole surface, often within the first twenty-four hours; procarpal structures and perithecial initials are well developed within thirty to sixty hours, and many fully formed perithecia con. taining ascogenous structures, asci or even liberated spores are to be found within ninety-six hours.

Below $37^{\circ} \mathrm{C}$. and above $55^{\circ} \mathrm{C}$, growth on 3 per cent malt extract agar slows down markedly and ceases between $25^{\circ}$ and $26^{\circ} \mathrm{C}$. and between $61^{\circ}$ and $62^{\circ} \mathrm{C}$.

This remarkable fungus, which is probably a new species, surely holds the high-temperature record for vegetative growth and production of perithecia among Ascomycetes. Its taxonomic position is still under consideration; but as soon as this has been decided, further data, including descriptive details, will be published.

Mushroom Research Association, Ltd.

$$
\text { C. J. LA TOUCHE }
$$

Yaxley, Peterborough, Northants.

\section{Treatment of Apple Canker Lesions with Plant-growth Substances}

GIVEN that the formation and spread of a canker depends on the balance between the growth of the pathogen and the regeneration of the host, a substance which stimulates wound healing may prove as effective in combating the disease as one which aims at suppressing the pathogen. A number of the chemicals known as plant-growth substances stimulate callus formation, and it is possible that some of these may also suppress the development of the pathogen.

The effect of a number of growth substances on Nectria galligena Bres., the cause of apple canker, has been examined. In the first method used, records were made of the growth of the fungus on 2 per cent malt agar $(p \mathrm{H} 4 \cdot 8)$ to which had been added 100 p.p.m. of the substance. It was found that during the greater part of the growth the increase in diameter was constant, and it was therefore possible to calculate a coefficient of linear regression of diameter on time which gave a fair estimate of the average growth-rate. Secondly, the effect of these substances on the growth of the fungus in liquid culture was observed by comparing dry weights of colonies grown in nutrient solutions 